This item was submitted to Loughborough's Research Repository by the author.

Items in Figshare are protected by copyright, with all rights reserved, unless otherwise indicated.

\title{
Postconflict peacebuilding, liberal irrelevance and the locus of legitimacy
}

PLEASE CITE THE PUBLISHED VERSION

http://dx.doi.org/10.1080/13533312.2011.588388

\section{PUBLISHER}

(c) Taylor \& Francis

\section{VERSION}

AM (Accepted Manuscript)

\section{LICENCE}

CC BY-NC-ND 4.0

\section{REPOSITORY RECORD}

Roberts, David. 2019. "Postconflict Peacebuilding, Liberal Irrelevance and the Locus of Legitimacy". figshare. https://hdl.handle.net/2134/15353. 
This item was submitted to Loughborough's Institutional Repository (https://dspace.lboro.ac.uk/) by the author and is made available under the following Creative Commons Licence conditions.

\section{creative
commons}

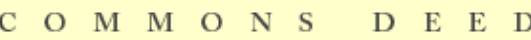

Attribution-NonCommercial-NoDerivs 2.5

You are free:

- to copy, distribute, display, and perform the work

Under the following conditions:

Attribution. You must attribute the work in the manner specified b the author or licensor.

Noncommercial. You may not use this work for commercial purposes.

No Derivative Works. You may not alter, transform, or build upon this work.

- For any reuse or distribution, you must make clear to others the license terms of this work.

- Any of these conditions can be waived if you get permission from the copyright holder.

Your fair use and other rights are in no way affected by the above.

This is a human-readable summary of the Leqal Code (the full license).

\section{Disclaimer 만}

For the full text of this licence, please go to: http://creativecommons.org/licenses/by-nc-nd/2.5/ 


\title{
Post-Conflict Peacebuilding, Liberal Irrelevance and the Locus of Legitimacy
}

\author{
DAVID ROBERTS
}

$[7,070]$

Key words: post-conflict peacebuilding, local legitimacy, global governance, popular peace

Post-conflict peacebuilding is failing, according to both its critics and its advocates. By way of solutions, proponents seek more of the same, whereas opponents argue for a radical shift. Both contain parts of a possible solution to the lack of local legitimacy that stigmatizes interventions, many of which descend into violence within five years and few of which produce democracies. This article advances the idea of a 'popular peace' that refocuses liberal institution building upon local, democratically-determined priorities deriving from 'everyday lives', in addition to internationally-favoured preferences (such as metropolitan courts and bureaucratic government). This is hypothesized to better confront the prevailing legitimacy lacuna, create social institutions around which a contract can evolve, and generate the foundations upon which durable peacebuilding may grow.

Changes in the axis of security with which Western academic discourse is concerned have forced frequent rethinking regarding sources of insecurity for the 'global north'. These changes have been accompanied by the movement of various security matters within and between academic disciplines, reflecting the importance with which they are viewed in academia. The question of how to build peace after war - peacebuilding - was once marginal to mainstream security debates. It now occupies a central position in the International Relations literature. Its relevance to the liberal peace notion has seen peacebuilding take centre stage in security debates and it is presently advanced as a means to achieve both local and international security. The approach, however, is increasingly under fire. Critics interrogate the nature and limits of the peace. ${ }^{1}$ They detect the hegemonic model's ontological narrowness; ${ }^{2}$ challenge the methodologies involved; ${ }^{3}$ note the diminution of the local in contemporary peacebuilding; ${ }^{4}$ and explain the failure of liberal institutionalism in terms of its questionable relevance to, and legitimacy for, substantial groups of the population in post-conflict spaces. $^{5}$ 
Advocates of the liberal orthodoxy concede that the Liberal Project, as Tom Young called it, ${ }^{6}$ is not securing the south for local or northern rationales. Their solution, however, involves refining the prevailing approach using the same methodologies based on the same ontological assumptions. ${ }^{7}$ They propose advanced technical solutions to deal with political matters. Its imaginary can be summarized as more of the same, ordered differently and more firmly applied. In response critics contend that this continues to ignore foundational, ontological and methodological matters and still lacks a radical, let alone inspired, vision of what peacebuilding might involve. ${ }^{8}$ Increasingly, critics point to the lack of local legitimacy as the key to understanding why peace does not prevail as intended. ${ }^{9}$ Orthodox peacebuilding is legitimated from without by its emphasis on state-centric liberalism but, according to critics, delegitimized within because peacebuilding priorities are irrelevant to much of the population's imminent needs. ${ }^{10}$ Priorities are not designed domestically and do not privilege the institutions locals would favour to deliver their needs. There is validity in these claims: whilst the process claims to be democratic and inclusive, local people are included primarily in the technical moment of elections. The process lacks any means of deliberation and dialogue to render inclusion and participation sufficiently meaningful to generate local legitimacy. ${ }^{11}$

This article is concerned with how peacebuilding can be made more relevant and legitimate to the people who must sanction the state-centrism that liberal peacebuilding prioritizes. It argues that the legitimacy upon which peacebuilding, states and peace rest cannot be generated by building institutions that ignore a population's priorities and imminent needs and which are irrelevant to conditions and contingencies as severe as those that routinely define post-conflict spaces. There is little evidence that new or rebuilt states identify and deliver those public priorities; so the state cannot acquire the broad legitimacy upon which its authority depends. This paradox is aggravated by international policy that denies state subsidization of collective needs, and by neglecting and aggravating the absence of a social contract. The article argues that the provision of local needs is central to generating internal, local legitimacy, which in turn is a key to stability and peace. The article first explains the idea of 'the everyday' and then examines how this could inform and structure a 'popular peace' served by global governance in accordance with core liberal values. It considers the peace people might ask for, rather than the peace interventionists believe they should have.

\section{The Everyday}


Peacebuilding literature is increasingly informed by the notion of the 'everyday'. Phillip Darby suggests that academics and researchers 'need to go out into the world and to connect with the everyday', adding that that 'there are steps that can be taken to encourage ordinary people on both sides of the North-South divide to become more involved in shaping the climate of thinking about peace settlements'. ${ }^{12}$ Numerous others, including this author, have implicitly or explicitly advanced this notion, to varying degrees, in terms of indigenous approaches to peace. ${ }^{13}$ Necessarily, in their engagement with local people researchers have to engage with the everyday lived lives of those people. But what is meant by 'everyday life'?

Michel de Certeau wrote that 'everyday life' is made up of 'the innumerable practices by means of which users reappropriate the space organized by techniques of sociocultural organization', whether that 'sociocultural organization' derives from local government or global governance. For de Certeau, this equates to the 'surreptitious reorganization of power'. ${ }^{14}$ Boege et al. write that such practices involve: '[c]ustomary law, traditional societal structures (extended families, clans, tribes, religious brotherhoods, village communities) and traditional authorities (such as village elders, headmen, clan chiefs, healers, bigmen, religious leaders)', in determining 'the everyday social reality of large parts of the population in developing countries... particularly in rural and remote peripheral areas'. ${ }^{15}$ Inevitably, 'the everyday' is concerned with a broader imagining of security, one that stands at odds with the idea of security privileged in peacebuilding. The latter is concerned with securing the state by allocating to it the sole legitimate use of violence, in Weberian, liberal fashion. But in the extreme conditions of post-conflict spaces, 'the everyday' is concerned with matters that secure the individual from routine, day-to-day contingencies unfamiliar to most international policymakers in the field of peacebuilding.

Such threats to everyday life commonly involve the war-aggravated poverty that strips clothing from people's backs, destroys their shelter and excludes from their lives basic nutrition, jobs and access to clean water. Combined, these contingencies kill people, or render them destitute, poverty-stricken, ill, illiterate and vulnerable to abuse. Their personal spaces are sometimes partly secured from direct violence by peacebuilding priorities such as security sector reform, but peacebuilding does little to nourish the everyday practices people deploy to secure themselves from the pervasive threats of indirect violence that are not the subject of statebuilding and peacebuilding. The claim that economic development will fix this eventually involves sacrificing lives in post-conflict spaces to an economic theory of neoliberalism that since 2007 has indubitably affirmed its propensity to collapse, ensure massive inequality of distribution and destroy lives and livelihoods. Persisting solely with such 
an unstable and dangerous approach which, even when it does work, can take years to 'trickle-down', reveals an arrogant and egregious lack of consideration for people in whose name peacebuilders exist. Interventionists often neglect the hardships of the everyday because they rarely see them for any length of time and almost never experience them. Waiting for a 'trickle-down wealth' effect is not a solution to immediate needs. Understanding 'the everyday' in extreme post-conflict spaces as a reaction to chronic personal insecurity, as well as to a range of other contingencies, illuminates the importance of 'the everyday'. It may be considered self-actualizing human security as encapsulated by Michel Foucault's 'technologies of the self'. ${ }^{16}$ Darby notes this understanding of security and the ways and means of the everyday when he writes that 'the most promising approach [to peacebuilding may] be anchored in the concept of self-securing.... Self-securing unsettles the understanding that security is best handled from "above"' in the liberal tradition of security from the perspective of the State. ${ }^{17}$ This representation of 'the everyday' destabilizes the priorities placed around post-conflict security, paving the way for local people to identify and discern how they define security and insecurity. This reveals security as subjective, reminding peacebuilders that, in the extreme conditions of post-conflict spaces, people are normally 'uninsured', to use Mark Duffield's conceptualization. ${ }^{18}$ Vulnerable people will necessarily prioritize solutions to poverty, joblessness and poor health above liberal institutionalization located in a distant, and disconnected, metropolis.

The 'everyday' is used here to refer to and illustrate the myriad socially-sanctioned ways in which, to secure their being, people outsmart their environmental limitations and manage the gaps between constraints and aspirations in the face of inadequate, disinterested and incompetent authority and power. It refers to the ways people make their lives the best they can, manipulating with whatever tools and tactics at their disposal, the surrounding natural, social, economic and political structures, local and global, that empower or constrain their lives. In the vandalized environment of post-conflict spaces, the everyday is biopolitical resilience: the application of 'silent technologies [which] determine or short-circuit institutional stage directions [and] the popular procedures [that] manipulate the mechanisms of discipline and conform to them only in order to evade them'. ${ }^{19}$ We may think of this as the manipulation of disempowering and asymmetrical power. It is in this sense an indigenous biopolitical response to exogenous biopolitical intervention. 'Everyday life' is immanent, imminent, ingrained and legitimated as a routine for populations in very poor and post-conflict spaces. It finds expression in informal activities from selling out-of-date aspirins outside refugee camps to police bribing motorists, and survival mechanisms, from children taking food from people in 
outdoor restaurants to scavenging on rubbish tips. It is the routines of life that empower people to manage their existences to the best of their abilities without reference to formal regulation of the private sphere by the biopolitical state.

\section{Mechanisms of 'The Everyday'}

Development and anthropology scholars have long understood the role of such practices in compensating for resource shortages, practised formally and informally among people who rely on them for everyday survival and basic nutritional-physiological needs. ${ }^{20}$ Such transactions routinely involve subsistence living and tend to be relatively small scale, in contrast with elite larceny, which is normally much larger in scale and less widely redistributive. Schmuel Eisenstadt and Luis Roniger call such small-scale transactions 'generalized exchange'. ${ }^{21}$

Vicky Randall and Robin Theobald also note that in the societies in which such forms of social behaviour are legitimatized and routine, people 'often live at the margin of subsistence' and 'not infrequently, [they] are driven below this margin by the vicissitudes of their existence: flood, drought, diseases, sickness, death, violence and intimidation by outsiders'. ${ }^{22}$ Family and kin may provide vital sustenance in a process sometimes referred to as 'informal welfare', and these exchanges and gifts will often be reciprocal and loosely equivalent. Where the family or local community cannot or will not intervene to ameliorate such conditions, however, and when the state and the market do not provide welfare, vulnerable people often turn to a more powerful individual such as their landlord, or a village chief, or a wealthy business person. Such relationships involve 'an exchange between a superior patron or patron group and an inferior client or client group [in which] the low-status client will receive material assistance in one form or another whilst his patron will receive less tangible resources such as deference, esteem, loyalty [or] personal services'. ${ }^{23}$ Daniel Ogbaharya refers to these practices as 'the social norms, customs, and networks that allocate and manage the economic and environmental resources of communities' at sub-state levels. ${ }^{24}$ They may involve low-level state employees, from underpaid police extracting 'fines' from motorists to medical staff operating taxis instead of attending clinics where they may not be paid for months. They often involve local people exchanging goods and services in a more or less equal fashion as well as involving unequal relationships between stronger and weaker individuals. Necessity, practicality and legitimacy are common themes in the mechanisms of 'the everyday' that can be referred to as Common Social Exchange (CSE). The normality of 
such relationships is represented in slang, demonstrating their pervasiveness. In Cambodia, the term khsae, or 'strings', denotes the winding connective networks of essential sustenance and loyalty.

Despite their legitimacy and necessity, CSE is commonly dismissed for the challenge it represents to the formal economy and its institutions. Visualizing and understanding the importance and function of these mechanisms throw the relevance and consequence of orthodox priorities into sharp relief, contrasting the necessity and legitimacy of the former with the privileged incongruity of the latter. Peacebuilding does not cater for the everyday, imminent needs of millions of people. This is central to understanding how and why people may not view prevailing peacebuilding priorities as legitimate.

'The everyday', when elaborated and displayed, presents a gateway for rethinking the priorities of peacebuilding around values shared among peacebuilders and people in war-torn societies. Maintenance and enhancement of 'the everyday' provides an alternative focus for the development of legitimacy, which in turn underpins stability and thence local peace. There can be no international liberal peace without national, local peace. Whereas orthodox peacebuilding has lacked attention to 'the everyday', critics have demonstrated conceptual awareness but have not evolved methods and policies for realizing the potency of their vision. From both perspectives 'the everyday' may represent an opportunity to refocus peacebuilding in ways that address the lacunae in legitimacy, sustain the development of local peace, and theoretically support the peace more broadly. It would be a more popular peace.

\section{Popular Peace and Liberal Peacebuilding}

If this better describes 'the everyday' and illuminates the matters of immediacy, relevance and legitimacy for people, how might international interventions respond? First, the routines of 'the everyday' can act as a guide to social and economic needs and the legitimacy of the institutions and practices sustaining them, in contrast with prevailing, and failing, priorities in liberal peacebuilding. Second, 'the everyday' acts as a focal point for the organization and mobilization of effective state delivery of public needs. It is a guide to the areas of private life that the public sector and the sentient state can serve and thereby legitimate themselves. In short, being able to better 'see' and comprehend 'the everyday' focuses the rationale of the re/forming state around (heterogeneous) popular will, endorsing the state's democratic and liberal credentials (in the sense of having a social contract) to which public loyalty could bond. Third, mobilizing state provision around peaceful, popular preferences identified with 
democratic instruments attuned to the variety of popular needs could make peacebuilding more responsive, participatory and emancipatory. In listening to and hearing diverse groups within a population, the state honours the will of the people and liberates liberal peacekeeping from the confines of its discourse and nomenclature, and the frailties of the peace it privileges. The outcome of acknowledging, hearing and responding to everyday lives is 'popular peace'. It is more than basic needs provision. It is the democratization of peacebuilding by making it genuinely participatory, such that the popular will of society determines the nature of the peace to be built, whatever that might be, as long as it peacefully reflects the electorate's will.

This is not the same as solely indigenous peacebuilding, at the opposite end of the spectrum to the hegemonic model. The debate between orthodox and critical schools turns on the balance between international and local determinism. Neither works well on its own, but they do not have to. The intellectual divide implies to some that orthodox and critical schools are mutually exclusive. ${ }^{25}$ On the contrary, the former shows signs of recognizing the merit of local legitimacy debates to be found in the latter. ${ }^{26}$ And critics consider various aspects of liberal ideology invaluable, ${ }^{27}$ but not the elements that relegate millions behind a limited peace for a limited minority, that are exclusive of substantial groups of people, or that support participation in and ownership of little more than political nomenclature and technical processes and a propensity for form over function. Thus, although critical scholarship 'recognizes the dangers of hegemony and of ignoring the basic needs of individuals in societies in favour of governments, states and elites', ${ }^{28}$ it does not preclude a role for liberalism in postconflict peacebuilding. Instead, critics imagine a peace that might 'offer empathy and care... contribute to a social contract, recognize cultural dynamics, offer everyday resources, and rest on a responsive social contract between local societies and the international peacebuilders, which might eventually make it self-sustaining'. ${ }^{29}$

But, as Roland Paris points out, critical scholarship does not go much further than these imaginings. ${ }^{30}$ Where orthodox peacebuilding scholarship has shown itself uncritical and unwilling to engage with the everyday, critical peacebuilding has been willing but unable to advance working alternatives to the existing orthodoxy (as opposed to abstract thinking). A viable alternative bridging the two schools of thought would have to satisfy core aspects of the prevailing liberal hegemony and top-down emphases on ideology and elitism, whilst simultaneously advancing bottom-up methods concerned with the mass of ordinary people's lives. Can this happen? Whilst the values underpinning a belief in the essentialism of liberalism to long-term planning privileging markets and institutions do not centre the 
everyday and the imminent, they are not the only emphases of liberal peacebuilding. Liberalism and liberal peacebuilding involve a host of other values and objectives that mesh well with 'the everyday' and with critical peacebuilding preferences. A revised expression of liberalism to foster genuinely participatory and inclusive legitimacy, democracy and human rights for political development could satisfy elements of critique and the more pressing concerns and priorities of 'the everyday'. For example, a revised liberal peacebuilding could centre on the right to life and the right to water, both enshrined in various international covenants but considered only rhetorically for the developing world, as a starting point in peacebuilding engagement with post-conflict spaces and everyday lives. There is no more central right than the right to life; without this right being supported by all the actors responsible for determining who gets what, all other rights are meaningless. ${ }^{31}$ The limited scholarship that has surveyed everyday priorities in post-conflict spaces identifies a preference for shelter, clean water and sanitation, electricity and jobs. ${ }^{32}$ The evidence suggests that such needs are, in the immediacy of the post-conflict moment, more important to local people than restored courts sustaining abstract rights in distant capitals. The expression and realization of such public preferences are underpinned by key liberal values like participation, the social contract and political stability. While serving everyday needs, these practices simultaneously extend core liberal values and objectives.

How can stable state-society relations be achieved? These are technical matters and matters of political expression and international political economy. Water for instance, is easy enough to clean with cheap technologies, and basic education encourages safe treatment of water and waste. But the decision to prioritize it is distinctly political and economic; they cannot readily be separated at either the local or the global level. For example, various global institutions such as the World Bank refuse to support state welfare, arguing that such matters should be left to markets and non-state provision by charities and churches. The scale of intervention required to get post-conflict societies to a position where they can contemplate growth exceeds residual capacity, and transnational corporations are disinclined to engage in high-risk, low-return investment such as rural sanitation - even though safe water and sanitation are central to life. Such political and economic decisions exert power over life and are thus clearly biopolitical. The impact of local and global political economy priorities is routinely experienced in everyday life as ongoing poverty, vulnerability and the persistent sense that the state is disinterested in the population's immediate and most pressing priorities. This translates into a lack of relevance and legitimacy of institutions prioritized in 
statebuilding, and it misses an opportunity to engender the legitimacy missing from most international interventions.

These are matters of ideology and economic ontology and epistemology, but they are not insurmountable. In terms of political economy, one element of such a strategy could involve extending the existing institutional emphasis of liberal peacebuilding to national bodies concerned with everyday life and its priorities. For example, a revised form of peacebuilding could emphasise a national health infrastructure focused around whichever health needs are most pressing for the greatest number, following the historical European example. ${ }^{33}$ The emphasis is still state-centric and Weberian-orientated. But instead of prioritizing the kind of state institutions focused on a limited metropolitan minority such as courts of law, bureaucracies concerned with traffic rules, constabulary regulations relating to the wearing of various uniforms and drivers' licences and MoTs, or enforcing the rule of (liberal) law that disadvantages millions of poor landowners, ${ }^{34}$ the focus would be on those preferences identified by substantial majorities across a country, where normally most people live. Rural priorities will likely vary considerably from liberal preferences often confined to metropolitan areas. Everyday needs could be served and local legitimacy bolstered on the way to generating the kind of trust between state and society that lies at the heart of the social contract, upon which durable peace rests. This also draws on the notion of democracy emphasized in the prevailing approach, but renders it more meaningful. That is, rather than prioritizing elections that offer short term representation by corrupt elites who manipulate and pervert the process before, during and after elections, peacebuilding priorities might respond to collective needs with substantial and long-term institution-building that reflected the priorities of the electorate. This would both honour public will and deepen the relevance and legitimacy of this emphasis on democratic participation and inclusivity. It represents an opportunity to serve both local and global peace with a shift in emphasis on institutions, formal and informal, from those that privilege metropolitan minorities and international business to those that provide for peaceful priorities of the wider electorate. Metropolitan minorities (mainly elites and middle classes) are enabled by liberal peacebuilding - rather than the poor urban majority swollen by rural migrants whose former spaces are reduced and reclassified by urban spread and the remainder of the rural population. ${ }^{35}$

A process of more democratized and inclusive peacebuilding will of course be 'corrupted' as people adapt it to their everyday lives where it does not fit, and a definitively 'liberal' outcome is unlikely, were it the intention of international peacebuilders; but no more or less than the existing, failing approach, and western democracies are not bastions of 
propriety. For critics who suggest that such a proposition is Utopian, change begins with ideas and arguments, and it is better that than propagating a clearly dystopian model. Given the failure of the prevailing model and the tendency to repeat mistakes, apparent in Angola, Mozambique, the Democratic Republic of Congo, Namibia, Somalia, Uganda, Eritrea and Bosnia and Herzegovina, amongst many others, the time for examining alternatives is overdue.

To connect citizenry to a state, the public preferences of the former must be provided by the latter. But state capacity in post-conflict spaces is normally severely compromised by a combination of incapacity, underfunding and corruption. How can these be managed, with the objective of democratizing, legitimizing and disciplining the state in relation to the society over which it presides? I suggest that the existing mission and assumptions of peacebuilding are not changed conceptually but are instead redirected to focus on funding and monitoring state bodies that serve everyday lives, just as peacebuilding presently does with elite political institutions. Global governance institutions such as the World Health Organization (WHO) and World Bank could protect core liberal rights underpinning everyday priorities through state institutions such as a National Health Service, vital public utilities or nation-wide schooling. These could be monitored and conditioned through various disciplinary mechanisms such as international NGOs (Physicians for Human Rights, Transparency International) and lending regimes (International Monetary Fund, aid agencies) in the same way that metropolitan government is presently. This would sustain democratically- and peacefully-enunciated priorities and render the process relevant and legitimate to the society represented and served by the state. Because it is the population at large that offers or withholds state legitimacy, it is towards their needs that the balance of provision must evolve. This will mean shifting emphasis from political institution building serving ideals to institutions that serve societies' needs, releasing resources from the former to the latter and generating imminent legitimacy and authority. Once this has been established and a social contract stabilized, emphasis may shift to the longer-term political institution building that presently occupies centre ground in peacebuilding interventions. The institutions of global governance are essential to achieving this objective.

\section{The Role of Global Governance}

Global governance, the ideology and instruments that project liberal values globally, specifically to post-conflict spaces, ${ }^{36}$ encompasses opinion forgers such as Francis 
Fukuyama and the late Samuel Huntington, scholars, international organizations such as the UN and EU, private transnational actors such as Avocats sans Fontières, Human Rights First and Freedom House, small local charities and other bodies such as the Anti-Corruption Commission in Sierra Leone and the High Office of Oversight and Anti-Corruption in Afghanistan. The significance of liberal hegemony, and its obvious biopolitical ramifications (in that everyday life en masse is directly affected by the policies it prescribes and proscribes), is central to the positioning of global governance in this article.

Global governance possesses the potential for enabling a range of institutions to reduce the consequences of exposure to some of the most serious contingencies of everyday life in post-conflict spaces. In this sense, the potential for a more meaningful, representative, legitimate and democratic peace is enabled or constrained by the degree to which global structures favour or neglect popular priorities in peacebuilding interventions. Global governance institutions are already engaged in providing various technical commodities, and have at least three contributions to make to a popular peace that also sustains various liberal values and security interests in both North and South

The first contribution by global governance institutions would involve responding to everyday needs enunciated locally and democratically expressed. This might include, for example, the WHO and Western development charities which might facilitate water, sanitation and hygiene where it is identified by local people as a priority. Other international institutions can be matched to national, peaceful, prevailing priorities through state infrastructures, such as the International Labour Office and World Bank facilitating a Ministry of Employment and Chambers of Commerce to identify local labour needs and capacities. The UN Development Programme's Crisis Prevention and Recovery Report (2008) indicates that national health and transport infrastructure projects could help soak up unemployment and foster economic growth. ${ }^{37}$ The national institutions in question could be evolved in parallel with those metropolitan counterparts ordinarily prioritized in liberal peacebuilding but which neglect everyday life, and, in the process, fail to develop enough local legitimacy to secure the peace.

A second task of global governance would be to ensure states and other appropriatelyfocused agencies deliver what people have identified efficiently. 'Good governance' is presently funded in accordance with global governance values and audited, rewarded and/or punished for meeting various Weberian benchmarks of provision. The same mechanism applies here to other state institutions whose priorities focus on delivery for popular needs. There are various ways this might be achieved. Rewards could be offered for achieving objectives evaluated by local people using, for example, Most Significant Change indicators 
(as used by international development agencies since early experiments in Bangladesh in 1996). ${ }^{38}$ Another way might be to tie the provision of political institution-building in metropolitan centres to the successful establishment of broader-reaching practices that inclusively serve diverse popular preferences. Membership of important global covenants might also be tied to encouraging elites to broaden their remit to formalize and institutionalize care for vulnerable populations. In other words, in addition to privileging wider peace outside the capitals, global governance bodies concerned with traditional institution-building could use their disciplinary and punitive powers to condition elite politics towards social protection. This would respond not just to local needs and enhance peacebuilding, but would also confront the 'unbecoming' nature of liberalism reflected in its disdain for basic human rights honoured in the West. ${ }^{39}$ For example, it is illegal for water providers in the UK to cut off non-paying customers because it is a breach of a fundamental right, but water and sanitation where it is often lethally scarce forms no part of the liberal covenant with post-conflict spaces. It is hard not to call this hypocritical.

Thus, rather than excessive liberal authority determining what local people get, 'just enough' global governance responds to local demands and simultaneously delivers and disciplines state provision for democratically-determined needs. It is at this nexus, between the local and 'just enough' global governance, that popular peace resides and local legitimacy is fostered. A shift of this kind would nourish the provision of legitimacy and help to provide much needed internal stability. In this transversal, or horizontal popular peace (contrasting with the vertical, elite version), the successful execution of practices aimed at managing population contingencies will likely confer legitimacy on the institutions that provide for the population. Whether those institutions are rural or metropolitan, informal or formal, or a mixture of all, if they serve the needs of substantial population sectors, as opposed to a narrow elite, their relevance will likely render them legitimate, and they may be empowered by external support and moderated and disciplined through conditionality if violence emerges. In short, there are alternative compositions of peace that global governance could mobilize and sustain. Affirming everyday lives could direct global governance, comprising an enormous range of liberally-minded transnational initiatives with power over life. But how are these needs to be communicated democratically?

\section{Democratizing Liberal Peacebuilding: Making ‘Participation’ Participatory}


It was suggested above that the technical manifestation of elite 'change' through elections serves to disguise the lack of change regarding the political economy of everyday needs, while others have remarked that liberal hubris masks the lack of substantial change amongst elites. ${ }^{40}$ The failure of this technical form of democracy to manifest popular will can be countermanded by rendering democracy more 'political'. Peacebuilding favours the technical whilst the political life is relegated or ignored, a point made by Jens Sorenson and David Chandler, among others. ${ }^{41}$ The former is far easier than the latter. Politicizing democracy managing power and inequality more representatively - may be achieved by making representation more than just an election that authorizes a centralized elite without creating a process for its legitimation. It is one thing to enable participation through a technicallymanaged mass plebiscite. It is altogether another to empower people to have their democratic will realized through a representative and meaningful social contract. The state part of the contract is achieved through elections; the social does not follow in liberal peacebuilding, mainly because liberal peacebuilding does not engage with the needs of the broad population and 'the everyday'.

Achieving the technical has been the objective of top-down external liberal interventionists and their associated methods. 'Achieving the political' is the aim of a more inclusive and horizontal process that requires different methods to identify the will of the people beyond their choice of leaders who rarely lead or represent. ${ }^{42}$ A first step in democratizing post-conflict peacebuilding and transforming the technical into the political involves hearing the preferences of the electorate beyond their momentary voting preference. Phillip Darby suggests that:

It is increasingly apparent - if as yet insufficiently acted upon - that... this involves listening to and taking bearings from people outside what is usually understood to be the [technical] political process... In many situations, whether a peace can be made or maintained may depend more on these grounded, personalized understandings - experiential knowledge - than on the geopolitical calculations and theoretical postulates of those skilled in state-building and diplomatic negotiation. ${ }^{43}$

For peacebuilding to be relevant, and therefore legitimate, the built peace must reflect the peaceful interests and preferences of the people, serving and reflecting the popular will. Knowledge of these cannot be generated externally and then imported into post-conflict 
spaces; it stems from within, in a more genuinely democratic exercise. The realization of that will from without, through the state and from global patrons, will likely generate legitimacy and the grounds for a more equitable social contract.

The means by which such preferences may be communicated are many and varied. Social communication networks long predate peacebuilding; people have mobilized to achieve their objectives in innumerable ways and places through 'the everyday'. Physical and social infrastructures for communication exist as a matter of course and, where they have been broken by war, they may be readily rebuilt. ${ }^{44}$ There is no shortage of agency in most post-conflict spaces at grassroots levels through community and provincial based organizations, for example. There is no reason why their remit may not be expanded to a national level. Local representation could be communicated through digital bulletin boards. Community and provincial organizations could be equipped with laptops, generators and fuel, wirelessly networked, connecting people to the internet through mobile phone networks upgraded with amplifiers and boosters for regional reach. Even some slums have access to older computers and the internet. If there is no electricity in one area, the public will in a given area can be communicated by 'motos' (small motorcycles) or other locally-accessible communications. This process would support 'civil society organisations that... promote real participation in decision-making - not "consultations" with the public that rubber stamp decisions made elsewhere, or [which] ignore public demands that do not fit into donors' preconceived frameworks'. ${ }^{45}$ In short, people's needs can readily be communicated, and it does not have to be based on advanced technology, although this may help. Whilst many Western donors favour working with elites, that preference can be challenged by pointing to the long run interventions that have failed to liberalize elite practices in any meaningful way.

\section{Conclusion}

There is broad agreement that liberal peacebuilding has failed to secure the kind of peace that travels internationally. Advocates insist that through elite institutionalization peacebuilding implants particular liberal values from the top down. Critics maintain that this does not happen, and that the approach fails to engage with popular needs, undermining the sources of political legitimacy that lie at the heart of stability and durability. The elite bias also acts as a comment on the extent to which liberal peacebuilding is meaningfully liberal, participatory or democratic. The two schools of thought may converge, however, around a synthesis of the global and the local that extends the priorities of both. Liberal institutions can still lead the 
way, but they could serve the popular will before elite actors in the North and South. Critical research could better develop methods for identifying local priorities to which global governance could respond. The degree of relevance to everyday life of such institutions and priorities will likely determine the extent to which a population views them as legitimate and accepts the state. The concept and possible outcome can be labelled 'popular peace'.

Beginning with, and hearing, the everyday represents an opportunity to refocus orthodox peacebuilding in ways that address the existing lacuna in legitimacy, sustain the development of local peace, and theoretically support the liberal peace more broadly. This form of peace would be more genuinely representative, participatory and democratic than the prevailing model because it would emphasize institutional growth that serves the popular will and engenders a greater likelihood of loyalty than one in which institutions relegate or ignore public voices. It binds the everyday to legitimacy; it is a peace that is relevant, apposite and legitimate to a majority of everyday lives. It cannot be defined or determined by outsiders, but outsiders can at least act to remove some of the impediments to its realization. There is, in other words, no standardized blue-print for such a popular peace, since all everyday lived realities are influenced by an enormous range of social factors that differ from landscape to landscape. Peace is particular to context and messy in make-up, rather than formulaic, reactive rather than rigid, and can be better suited to spontaneous contingency, circumstance and complexity than the rehearsed rhetoric and ready rubric of orthodox peacebuilding and liberal ontology. For such a peace to be most effective, two agendas require consideration. The first is everyday need, the second liberal exceptionalism. The two are not necessarily mutually exclusive. Ultimately, popular peace could be 'emancipatory' not just for people in post-conflict spaces, but also for the liberal project, morally distressed and devalued by the distance between what it preaches in human rights rhetoric, and the practices it privileges in reality. Popular peace might reinvigorate the legitimacy of how peacebuilding interventions happen and what they seek to achieve, and salve an ideology of peace in serious trouble in terms of what it claims it can do and how best to do it. This is not the purpose of a popular peace - which is more about rescuing people from excessive ideological dogma and what seems like blind faith in a misplaced idea. But if liberal global governance were seen to be responding to mass need expressed peacefully and democratically, its reputation in the global South and to its critics everywhere may be at least partly restored.

Notes 
${ }^{1}$ Jens Sorensen, 'Balkanism and the New Radical Interventionism: a Structural Critique', International Peacekeeping, Vol.9, No.1, 2002, pp.1-22.

2 Oliver Richmond, Peace in International Relations, London: Routledge, 2008, p.109.

${ }^{3}$ Abigail Fuller, 'Toward an Emancipatory Methodology for Peace Research', Peace and Change, Vol.17, No.3, 1992, pp.286-311.

${ }^{4}$ Roger Mac Ginty, 'Indigenous Peace-Making Versus the liberal Peace ', Cooperation and Conflict, Vol.43, No.2, pp.139-163.

${ }^{5}$ Volke Boege, Anne Brown, Kevin Clements and Anna Nolan, 'On Hybrid Political Orders and Emerging States: What is Failing? States in the Global South or Research and Politics in the West?', in Martina Fischer and Beatrix Schmelzle (eds), Building Peace in the Absence of States: Challenging the Discourse on State Failure, Berlin: Berghof Research Centre, 2009, pp.15-31.

${ }^{6}$ Tom Young, 'A Project to be Realised': Global liberalism and Contemporary Africa', Millennium: Journal of International Studies, Vol.24, No.3, 1994, pp.527-46.

${ }^{7}$ Roland Paris, 'Saving Liberal Peacebuilding', Review of International Studies, Vol.36, No.2, 2010, pp.337-65; Simon Chesterman, You the People: The United Nations, Transitional Administration and State-building, Oxford: Oxford University Press, 2004. ${ }^{8}$ Oliver Richmond, (see n.2 above).

${ }^{9}$ Maria Bargh, Resistance: An Indigenous Response to Neoliberalism, Wellington, Aotearoa/New Zealand: Huia Publishers, 2007.

${ }^{10}$ David Chandler, 'The State-building dilemma: Good Governance or Democratic Government?', in Aiden Hehir and Neil Robinson, Statebuilding: Theory and Practice, London: Routledge, 2007, pp.70-88.

${ }^{11}$ David Roberts, Liberal Peacebuilding and Global Governance: Beyond the Metropolis, London: Routledge, 2011.

12 Philip Darby, 'Rolling Back the Frontiers of Empire: Practising the Postcolonial', International Peacekeeping, Vol.16, No.5, 2009, p.700.

${ }^{13}$ William Reno, 'Bottom-Up Statebuilding?', in Charles Call and Vanessa Wyeth, Building States to Build Peace, Boulder, Colorado: Lynne Rienner, 2008, pp143-61; Boege et al. (see n.5 above); Mac Ginty (see n.4 above); and Richmond (see n.2 above).

${ }^{14}$ Michel de Certeau, The Practice of Everyday Life, Berkeley, CA: California University Press, 1984, p.14. 
${ }^{15}$ Boege et al. (see n.5 above) (original italics).

${ }^{16}$ Michel Foucault, 'Technologies of the Self: A Seminar with Michel Foucault', in Luther H Martin, Huck Gutman and Patrick H Hutton, Technologies of the Self, Amherst, MA: University of Massachusetts Press, 1998, pp.16-49.

${ }^{17}$ Darby (see n.12 above), p.701.

${ }^{18}$ Mark Duffield, 'Global Civil War: The Non-Insured, International Containment and Post-Interventionary Society', Journal of Refugee Studies Vol.21, No.2, 2008, pp.14565.

${ }^{19}$ de Certeau (see n.14 above).

${ }^{20}$ Elizabeth Harrison, 'Corruption', Development in Practice, Vol.17, Nos.4-5, 2007, pp.672-78; Michael Bratton, 'Formal Versus Informal Institutions in Africa', Journal of Democracy, Vol.18, No.3, 2007, pp.96-110.

${ }^{21}$ Schmuel Eisenstadt and Luis Roniger, Patrons, Clients and Friends: Interpersonal Relations and the Structure of Trust in Society, Cambridge: Cambridge University Press, 1984, pp.49-55.

${ }^{22}$ Vicky Randall and Robin Theobald, Political Change and Underdevelopment: A Critical Introduction to Third World Politics, Basingstoke: Macmillan, 1985, p.52 23 Ibid.

${ }^{24}$ Daniel Ogbaharya, '(Re)building governance in post-conflict Africa: the role of the State and informal institutions', Development in Practice, 2008, Vol.18, No.3, pp.395402, p.396.

${ }^{25}$ Jenna Slotin, Vanessa Wyeth and Paul Romita, 'Power, Politics and Change: How International Actors Assess Local Context', report, International Peace Institute, New York, June 2010.

${ }^{26}$ Paris (see n.2 above).

${ }^{27}$ Richmond (see n.2 above); Roberts (see n.11 above)

${ }^{28}$ Oliver Richmond, 'Beyond liberal Peace?', in Edward Newman, Roland Paris and Oliver Richmond (eds), New Perspectives on Liberal Peacebuilding, Tokyo: UN University Press, 2009, p.73.

${ }^{29}$ Richmond (see n.2 above), p.72.

${ }^{30}$ Paris (see n.2 above).

${ }^{31}$ David Roberts, Global Governance and Biopolitics: Regulating Human Security, London: Zed, 2010. 
${ }^{32}$ Olivier Roy, 'Development and political legitimacy: the cases of Iraq and Afghanistan', Conflict, Security \& Development, Vol.4, No.2, 2004, pp.167-79; Ruth Rennie, Sudhindra Sharma and Pawan Sen, 'A Survey of the Afghan People: Afghanistan in 2009, 2009 (at: http://pdf.usaid.gov/pdf_docs/PNADT332.pdf); Federico Battera, 'State\& Democracy-building in Sub-Saharan Africa: the case of Somaliland - a comparative perspective', Global Jurist Frontiers, Vol.4, No.1, 2004, pp.1-3.

${ }^{33}$ George Rosen, A History of Public Health, Baltimore, MD: Johns Hopkins University Press, 1993.

${ }^{34}$ Stefan Andreasson, 'Stand and Deliver: Private Property and the Politics of Global Dispossession', Political Studies, Vol.54, No.1, 2006, pp.3-22; Jenny Peterson, 'Rule of Law initiatives and the liberal peace: the impact of politicised reform in postconflict states', Disasters, Vol.34, No.1, 2010, pp.15-39.

${ }^{35}$ Mark Montgomery, 'The Urban Transformation of the Developing World', Science, Vol.319, no.5864, pp.761-64; Halvard Buhaug and Henrik Urdal, 'An Urbanization Bomb: Population Growth and Social Disorder in Cities', report, Peace Research Institute Oslo, June 2010 (at: http://climsec.prio.no/papers/Buhaug\%20\%20Urdal\%20urbanization_climsec\%20June \%202010.pdf).

${ }^{36}$ Michael Dillon and Julian Reid, 'Global liberal Governance: Biopolitics, Security and War', Millennium: Journal of International Studies Vol.30, No.1, 2001, pp.41-66. 37 John Ohiorhenuan and Frances Stewart (leads), Post-Conflict Economic Recovery: Enabling Local Ingenuity, Bureau for Crisis Prevention and Recovery, UN Development Programme, New York, 2008, pp.48-105.

38 Jessica Dart, 'A Dialogical, Story-Based Evaluation Tool: The Most Significant Change Technique', American Journal of Evaluation Vol.24 No.2, 2003, pp.137-55 ${ }^{39}$ Oliver Richmond, 'Becoming liberal, Unbecoming Liberalism: Liberal-Local Hybridity via the Everyday as a Response to the Paradoxes of Liberal Peacebuilding', Journal of Intervention and Statebuilding Vol.3, No.3, 2009, pp.324-44.

40 Thomas Carothers, 'The End of the Transition Paradigm', Journal of Democracy Vol.13, No.1, 2002, pp.5-21; Michael Bratton and Nicholas van de Walle, 'Neopatrimonial Regimes and Political Transitions in Africa', World Politics Vol.46, 1994, pp.453-89 
${ }^{41}$ Sorensen (see n.1 above); David Chandler, Bosnia: Faking Democracy after Dayton, London: Pluto, 1999.

${ }^{42}$ Carothers (see $\mathrm{n} .40$ above).

${ }^{43}$ Darby (see n.12 above), p.712.

${ }^{44}$ Christian Lund, Twilight Institutions: Public Authority and Local Politics in Africa, Oxford: Blackwell, 2007.

${ }^{45}$ Diana Cammack, 'The Logic of African Neopatrimonialism: What Role for Donors?', Development Policy Review, Vol.25, No.5, pp.599-614. 